\title{
VARIABEL-VARIABEL YANG MENENTUKAN TINGKAT PROFITABILITAS BANK
}

\author{
Ni Putu Devi Anggarini ${ }^{1}$ \\ Ida Bagus Panji Sedana ${ }^{2}$ \\ ${ }^{1,2}$ Fakultas Ekonomi dan Bisnis Universitas Udayana, Bali, Indonesia \\ e-mail: devianggarini@ rocketmail.com
}

\begin{abstract}
ABSTRAK
Penelitian ini dilakukan pada BPR di Provinsi Bali. Data dalam penelitian ini adalah rasio keuangan dan laporan keuangan BPR periode tahun 2012 - 2016. Teknik pengambilan sampel dalam penelitian ini dengan menggunakan metode sensus Variabel independen dalam penelitian yaitu CAR, NPL, LDR, dan BOPO. Variabel dependen adalah rasio keuangan profitabilitas dengan indikator ROA. Analisis data dalam penelitian ini menggunakan teknik analisis diskriminan. Berdasarkan uji diskriminan dengan menggunakan simultance menyatakan bahwa model Unstandardized Canonical Discriminant Function dapat mengklasifikasi dua kelompok BPR berdasarkan nilai diskriminannya dengan tepat sebesar $79 \%$ dari total sampel. Hasil penelitian ini menunjukan LDR dan BOPO berpengaruh positif dan signifikan pada peningkatan tingkat Profitabilitas. CAR dan NPL tidak berpengaruh secara signifikan terhadap tingkat Profitabilitas. Biaya Operasional terhadap Pendapatan Operasional (BOPO) merupakan rasio keuangan yang paling dominan membedakan tingkat profitabilitas bank. Sehingga pengurus bank diharapkan lebih efektif dan efisien dalam pengelolaan biaya operasionalnya. Penelitian selanjutnya dapat meneliti variabel - variabel keuangan lainnya.
\end{abstract}

Kata Kunci: Rasio Keuangan, Capital Adequacy Ratio (CAR), Non Performing Loan (NPL), Loan to Deposit Ratio (LDR), Biaya Operasional Pendapatan Operasional (BOPO), Return on Asset (ROA)

\begin{abstract}
This research was conducted at BPR in Bali Province. Data in this research is financial ratio and financial report of BPR period year 2012-2015. Sampling technique in this research by using census method Independent variable in research that is $C A R, N P L, L D R$, and BOPO. Dependent variable is profitability financial ratios with ROA indicator. Data analysis in this research use discriminant analysis technique. Based on the discriminant test using simultance, the Unstandardized Canonical Discriminant Function model can classify two groups of BPR based on their discriminant value appropriately by $79 \%$ of the total sample. The result of this research shows that LDR and BOPO have positive and significant influence on the level of Profitability. CAR and NPL have no significant effect on Profitability level. Operational Cost of Operating Income (BOPO) is the most dominant financial ratios to differentiate bank profitability. So the bank management is expected to be more effective and efficient in managing its operational costs. Further research can examine other financial variables.
\end{abstract}

Keywords: Financial Ratio, Capital Adequacy Ratio (CAR), Non Performing Loan (NPL), Loan to Deposit Ratio (LDR), Biaya Operasional Pendapatan Operasional (BOPO), Return on Asset (ROA) 


\section{PENDAHULUAN}

Bank sebagai lembaga keuangan yang memberikan jasa keuangan yang paling lengkap. Otoritas Jasa Keuangan menurut Undang - Undang No. 23 Tahun 1999 tentang BI, sebenarnya sudah harus terbentuk pada 2002, namun praktiknya OJK ini baru terbentuk pada 2011 melalui Undang - Undang No. 21 Tahun 2011 yang disahkan pada 22 November 2011. Otoritas Jasa Keuangan adalah lembaga negara yang dibentuk berdasarkan pada Undang - Undang No. 21 Tahun 2011 yang berfungsi menyelenggarakan sistem pengaturan dan pengawasan yang terintegritas terhadap keseluruhan kegiatan didalam sektor jasa keuangan.

Usaha keuangan yang dilakukan disamping menyalurkan dana atau memberikan pinjaman (kredit) juga melakukan usaha menghimpun dana dari masyarakat luas dalam bentuk simpanan (Kasmir, 2011:3). Menghimpun dana dari masyarakat dan menyalurkan kembali dana tersebut kepada masyarakat luas untuk berbagai tujuan atau sebagai financial intermediary. Berdasarkan dari kegiatan utama perbankan, sektor pinjaman atau kredit yang disalurkan oleh perbankan mempunyai peranan yang besar terhadap pertumbuhan ekonomi.

Hal ini karena kredit yang digunakan oleh pengusaha untuk kegiatan produktif akan memberikan nilai tambah terhadap faktor produksi. Selain itu, kredit juga digunakan untuk membiayai pembelian untuk barang-barang konsumsi. Kegiatan tersebut akan meningkatkan pertumbuhan ekonomi. Pengusaha memproduksi barang atau jasa yang akan meningkatkan pendapatan, disisi lain produk mereka dikonsumsi oleh masyarakat. 
Perbankan yang segmen pasarnya lebih banyak pada pengusaha UKM (Usaha, Kecil dan Menengah) adalah Bank Prekreditan Rakyat (BPR). Bank Perkreditan Rakyat didefinisikan oleh Undang - Undang Nomor 10 Tahun 1998 sebagai bank yang melaksanakan kegiatan usaha secara konvensional dan/atau berdasarkan prinsip syariah yang dalam kegiatannya tidak memberikan jasa dalam lalu-lintas pembayaran. BPR dalam melakukan kegiatannya sebagai lembaga keuangan bank yang menerima simpanan hanya dalam bentuk deposito berjangka, tabungan dan/atau bentuk lain yang dipersamakan dengan itu dan menyalurkan dana dalam bentuk kredit atau dalam bentuk lain dalam rangka meningkatkan taraf hidup masyarakat yang melaksanakan kegiatan usahanya melalui prinsip konvensional atau berdasarkan prinsip syariah yang dalam kegiatannya tidak memberikan jasa dalam lalu lintas pembayaran (Zulfikar, 2014).

Bank Perkreditan Rakyat, sebagaimana lembaga perbankan lainnya, melaksanakan fungsinya menghimpun dana masyarakat dan menyalurkannya kembali kepada masyarakat dalam bentuk kredit. Pemerintah juga mengatur untuk didirikannya Bank Perkreditan Rakyat yang lingkup kerjanya lebih terpusat pada wilayah tertentu saja misalnya di Kabupaten, Kecamatan dan Desa. Hal ini dilakukan untuk dapat merangkul masyarakat ekonomi lemah. BPR berasal dari Bank Desa, Bank Pasar, Lumbung Desa, Bank Pegawai, dan bank lainnya yang kemudian dilebur menajadi Bank Perkreditan Rakyat.

Semakin banyaknya jumlah bank, maka dana-dana masyarakat yang berhasil dihimpun oleh bank semakin meningkat sehingga menyebabkan meningkat pula penyaluran kredit. Secara lebih spesifik bank dapat berfungsi 
sebagai agent of trust, agent of development dan agent of service (Budisantoso \& Nuritomo, 2015:11). Masyarakat sebagai pihak yang paling berperan, pada umumnya memiliki sikap tanggap terhadap berbagai bentuk pelayanan yang diberikan oleh masing-masing bank untuk menarik simpati masyarakat. Simpati dan kepercayaan masyarakat terhadap suatu bank tidak terlepas dari keadaan keuangan bank, termasuk kesehatan bank tersebut. Kinerja keuangan bank merupakan gambaran kondisi keuangan bank pada suatu periode tertentu baik mencakup aspek penghimpunan dana maupun penyaluran dananya (Adyani, 2011). Penilaian terhadap kinerja suatu bank dapat dilakukan dengan melakukan analisis terhadap laporan keuangnya. Laporan keuangan bank berupa neraca memberikan informasi kepada pihak di luar bank, misalnya bank sentral, masyarakat umum, dan investor, mengenai gambaran posisi keuangannya, yang lebih jauh dapat digunakan pihak eksternal untuk menilai besarnya risiko yang ada pada suatu bank.

Laporan keuangan perbankan akan sangat buruk dengan adanya negativenet income dan kewajiban penyedia modal minimum (Capital Adequacy Ratio) yang tidak terpenuhi. Modal merupakan faktor terpenting yang menjadi kepercayaan masyarakat. Jika Capital Adequacy Ratio semakin tinggi maka semakin kuat kemampuan bank tersebut untuk menanggung risiko dari setiap kredit atau aktiva produktif yang berisiko, keadaan yang menguntungkan bank tersebut akan memberikan kontribusi yang cukup besar bagi profitabilitas. Rasio profitabilitas yang penting bagi bank adalah Return On Asset (ROA). 
Rasio-rasio bank yang mempengaruhi ROA adalah: Capital Aquedacy Ratio (CAR), Non Performing Loan (NPL), Loan to Deposit Return (LDR) dan Biaya Operasional Pendapatan Operasional (BOPO). Rasio CAR, NPL, LDR dan BOPO yang baik, akan mendukung kemampuan bank dalam menciptakan laba (profitabilitas). Beberapa penelitian terdahulu tentang profitabilitas (ROA) bank dengan menggunakan rasio keuangan tertentu. Penelitian yang dilakukan Pratiwi (2012) menemukan hasil bahwa CAR dan BOPO tidak berpengaruh signifikan terhadap ROA. Adyani (2011) juga menemukan hasil yang sama bahwa CAR dan BOPO tidak berpengaruh signifikan terhadap ROA. Premani \& Badjra (2014) menunjukkan bahwa CAR berpengaruh signifikan terhadap ROA. Tetapi BOPO tidak berpengaruh signifikan terhadap ROA. Utami (2015) bahwa CAR dan LDR berpengaruh positif terhadap ROA, sedangkan BOPO tidak berpengaruh signifikan.

Hantono (2017) menemukan bahwa CAR, LDR dan NPL tidak berpengaruh signifikan terhadap ROA. Paulin (2015) juga menemukan jika NPL dan BOPO tidak berpengaruh signifikan terhadap ROA. Berbeda dengan Cai \& Huang (2014) yang menemukan bahwa NPL dan BOPO berpengaruh signifikan terhadap ROA. Buchory (2015) bahwa NPL dan BOPO berpengaruh signifikan terhadap ROA. Rengasamy (2014) juga menemukan NPL berpengaruh signifikan terhadap ROA. Abdullah (2014) menemukan bahwa BOPO berpengaruh signifikan terhadap ROA.

Adapun rumusan masalah dalam penelitian ini adalah apakah Capital Adequency Ratio (CAR),Non Performing Loans (NPL), Loan to Deposit Ratio 
(LDR), Biaya Operasional atas Pendapatan Operasional(BOPO) mampu membedakan tinggi rendahnya profitabilitas pada BPR di Provinsi Bali?

Kerangka berfikir yang melandasi penelitian ini adalah variabel - variabel yang mampu menentukan tinggi rendahnya profitabilitas pada Bank Perkreditan Rakyat (BPR) di Provinsi Bali. Tentunya dengan mengetahui rasio keuangan yang membedakan tinggi rendahnya profitabilitas BPR. Secara teoritis tinggi rendahnya ROA tergantung pada pengelolaan aset perusahaan oleh manajemen yang menggambarkan efisiensi dari operasional perusahaan. Semakin tinggi ROA semakin efisien operasional perusahaan dan sebaliknya, rendahnya ROA dapat disebabkan oleh banyaknya aset perusahaan yang menganggur, investasi dalam persediaan yang terlalu banyak, kelebihan uang, aktiva tetap beroperasi dibawah normal dan lain-lain.

Modal bank merupakan "engine" dari pada kegiatan bank, kalau kapasitas mesinnya terbatas maka sulit bagi bank tersebut untuk meningkatkan kapasitas kegiatan usahanya khususnya dalam penyaluran kredit. Kegiatan utama dari bank yaitu menghimpun dana dan menyalurkan dana tersebut kembali dalam bentuk kredit. Jika CAR cukup atau memenuhi kententuan, maka bank tersebut dapat beroperasi sehingga terciptalah laba. Semakin tinggi CAR, maka semakin baik kinerja dari suatu bank. Penyaluran kredit yang optimal, dengan asumsi tidak terjadi macet, maka akan mampu menaikkan laba yang pada akhirnya akan meningkatkan profitabilitas (ROA).

Wibowo \& Syaichu (2013) menjelaskan bahwa semakin tinggi CAR maka semakin baik kemampuan bank tersebut untuk menanggung risiko dari setiap 
aktiva produktif yang berisiko. Hal tersebut berarti, jika nilai CAR tinggi maka bank tersebut mampu membiayai kegiatan operasionalnya dan memberikan kontribusi yang cukup besar bagi profitabilitas. Sehingga modal bank cukup besar dan mampu melindungi deposan serta akan meningkatkan kepercayaan deposan terhadap bank tersebut.

Penelitian yang dilakukan oleh Premani \& Badjra (2014) menemukan bahwa CAR berpengaruh signifikan terhadap profitabilitas (ROA). Susanto \& Kholis (2016) menyatakan bahwa CAR memiliki pengaruh yang positif dan signifikan terhadap profitabilitas. Penelitian lain yang dilakukan oleh Utami (2015) juga bahwa CAR berpengaruh positif terhadap ROA. Berdasarkan uraian tersebut, maka hipotesis dalam penelitian ini dapat dirumuskan sebagai berikut :

$\mathrm{H}_{1}$ : Capital Aquedacy Ratio(CAR) berpengaruh positif dan signifikan terhadap tinggi rendahnya profitabilitas (ROA).

NPL merupakan rasio yang dipergunakan untuk mengukur kemampuan bank dalam mengukur risiko kegagalan pengembalian kredit oleh debitur. Non performing loan adalah kredit yang bermasalah dimana debitur tidak dapat memenuhi pembayaran tunggakan peminjaman dan bunga dalam jangka waktu yang telah disepakati dalam perjanjian. NPL tersebut mencerminkan risiko kredit, jika semakin kecil NPL maka semakin kecil pula risiko kredit yang akan ditanggung oleh pihak bank. Sehingga jika semakin besar Non Performing Loan (NPL), akan mengakibatkan menurunnya return on asset, yang juga berarti kinerja keuangan bank yang menurun. Begitu pula sebaliknya, jika non performing loan (NPL) turun, maka return on asset (ROA) akan semakin 
meningkat, sehingga kinerja keuangan bank dapat dikatakan semakin baik. Semakin besar tingkat NPL menunjukkan bahwa bank tersebut tidak profesional dalam pengelolaan kreditnya, sekaligus memberikan indikasi bahwa tingkat risiko atas pemberian kredit pada bank tersebut cukup tinggi searah dengan tingginya NPL yang dihadapi bank (Riyadi, 2006: 161). Oleh sebab itulah, maka pemberian kredit yang dilakukan oleh bank harus melakukan analisis terlebih dahulu terhadap kemampuan debitur untuk membayar kembali kewajibannya. Setelah kredit diberikan bank wajib melakukan pemantauan terhadap penggunaan kredit serta kemampuan dan kepatuhan debitur dalam memenuhi kewajibannya.

Penelitian yang dilakukan oleh Cai \& Huang (2014) menyatakan bahwa NPL berpengaruh signifikan terhadap profitabilitas (ROA). Penelitian lain yang dilakukan oleh Rengasamy (2014) juga menemukan bahwa NPL berpengaruh signifikan terhadap ROA. Buchory (2015) menyatakan bahwa Non Performing Loan (NPL) memiliki pengaruh signifikan terhadap profitabilitas, hasil yang sama ini juga temukan oleh Susanto \& Kholis (2016). Buchory (2015) bahwa NPL berpengaruh terhadap terhadap ROA. Hindarto (2011) menemukan hasil bahwa NPL berpengaruh negatif dan signifikan terhadap ROA. Berdasarkan uraian tersebut, maka hipotesis dalam penelitian ini dapat dirumuskan sebagai berikut :

$\mathrm{H}_{2}$ : Non Performing Loan (NPL) berpengaruh negatif dan signifikan terhadap tinggi rendahnya profitabilitas (ROA).

Likuiditas bank merupakan suatu kemampuan bank dalam memenuhi kewajiban jangka pendeknya. Hal tersebut berarti bank mampu membayar kembali pencairan dana deposannya pada saat ditagihkan serta dapat mencukupi permintaan kredit yang telah diajukan (Kasmir, 2014: 315). Semakin tinggi LDR 
maka semakin tinggi dana yang disalurkan ke dana pihak ketiga. Jika bank mampu menyalurkan kredit secara maksimal, namun tetap mampu menjaga agar tingkat Loan to Deposit ratio berada pada batas aman yaitu 78-100 persen maka profitabilitas yang dicapai akan lebih maksimal.

Penelitian yang dilakukan Utami (2015) menyatakan bahwa LDR berpengaruh signifikan terhadap ROA. Rengasamy (2014) dalam penelitiannya juga menyatakan bahwa Loan to Deposit Ratio (LDR) memiliki pengaruh yang signifikan terhadap profitabilitas. Penelitian yang dilakukan oleh Purnamawati (2014) menyatakan LDR berpengaruh positif dan signifikan terhadap profitabilitas. Berdasarkan uraian tersebut, maka hipotesis dalam penelitian ini dapat dirumuskan sebagai berikut :

$\mathrm{H}_{3}$ : Loan to Deposit Ratio berpengaruh positif dan signifikan terhadap tinggi rendahnya profitabilitas (ROA).

BOPO juga merupakan variabel yang mampu membedakan bank yang mempunyai profitabilitas (ROA) diatas rata-rata maupun bank yang mempunyai profitabilitas (ROA) dibawah rata-rata. Pengelolaan aktivitas operasional sebuah bank yang efisien adalah dengan memperkecil biaya operasional bank yang nantinya akan sangat mempengaruhi besarnya tingkat keuntungan bank yang akan tercermin dalam ROA sebagai indikator yang mencerminkan efektivitas perusahaan dalam menghasilkan laba dengan memanfaatkan keseluruhan aktiva yang dimilikinya. Maka efisiensi bank dapat tercapai dengan beberapa cara, yaitu salah satunya adalah dengan meningkatkan pendapatan operasi dengan memperkecil biaya operasi, atau dengan biaya operasi yang sama akan dapat meningkatkan pendapatan operasi sehingga pada akhirnya akan meningkatkan 
keuntungan bank. Tetapi jika semakin besar perbandingan total biaya operasi dengan pendapatan operasi, maka akan berakibat turunnya ROA.

Penelitian yang dilakukan oleh Pratiwi (2012) menyatakan bahwa BOPO tidak berpengaruh signifikan terhadap ROA. Paulin (2015) menyatakan Biaya Operasional atas Pendapatan Operasional (BOPO) berpengaruh negatif dan signifikan terhadap profitabilitas. Hasil yang sama juga ditemukan oleh Buchory (2015) menyatakan bahwa BOPO memiliki pengaruh negatif dan signifikan terhadap profitabilitas. Adyani (2011) juga menyatakan BOPO tidak berpengaruh signifikan terhadap ROA. Penelitian yang dilakukan oleh Kristianti (2016) menyatakan bahwa BOPO berpengaruh signifikan terhadap ROA dengan arah negatif. Berdasarkan uraian tersebut, maka hipotesis dalam penelitian ini dapat dirumuskan sebagai berikut :

$\mathrm{H}_{4}$ : Biaya Operasional atas Pendapatan Operasional berpengaruh negatif signifikan terhadap tinggi rendahnya profitabilitas (ROA).

\section{METODE PENELITIAN}

Variabel dependen dalam penelitian ini adalah kelompok BPR dengan ROA tinggi dan kelompok BPR dengan ROA rendah. Variabel independen dalam penelitian ini yaitu terdiri dari 4 variabel antara lain Capital Adequency Ratio (CAR), Non Performing Loans (NPL), Loan to Deposit Ratio (LDR), dan Biaya Operasional atas Pendapatan Operasional(BOPO).

Data Kuantitatif merupakan data yang dapat dihitung dalam bentuk angkaangka, dalam penelitian ini menggunakan data laporan keuangan publikasi BPR konvensional periode 2012-2016. Data keuangan meliputi data mengenai Capital 
Adequency Ratio (CAR), Non Performing Loans (NPL), Loan to Deposit Ratio (LDR), Biaya Operasional atas Pendapatan Operasional (BOPO). Data kualitatif merupakan data yang tidak berupa angka - angka tetapi merupakan keterangan yang berhubungan dengan masalah yang diteliti, dalam penelitian ini seperti Peraturan Otoritas Jasa Keuangan (PJOK) tentang Kewajiban Penyediaan Modal Minimum bagi BPR.

Penelitian ini menggunakan sumber data yaitu data sekunder. Data sekunder yang digunakan pada penelitian ini diperoleh dari publikasi laporan keuangan yang memberikan informasi mengenai rasio keuangan BPR di Provinsi Bali tahun 2012 sampai 2016, yaitu rasio Return On Asset (ROA), Capital Aquedacy Ratio (CAR), Non Performing Loan (NPL), Loan to Deposit Ratio $(L D R)$, dan Biaya Operasional Pendapatan Operasional (BOPO) yang tersedia pada website Bank Indonesia (www.bi.go.id) dan website Otoritas Jasa Keuangan (www.ojk.go.id).

Populasi penelitian ini yaitu menggunakan seluruh Bank Perkreditan Rakyat (BPR) konvensional yang ada di Provinsi Bali. Jumlah populasi penelitian ini adalah 137 BPR. Teknik pengambilan sampel dalam penelitian ini dengan menggunakan metode sensus. Jumlah sampel sebanyak 122 perusahaan yang mengeluarkan laporan keuangan tahunan publikasi yang sudah diaudit di Otoritas Jasa Keuangan periode 2012 - 2016. Metode pengumpulan data yang digunakan dalam penelitian ini untuk memperoleh data yang akan dianalisis adalah teknik dokumentasi, yaitu cara pengumpulan data dengan mengambil catatan dan dokumen yang berkaitan dengan permasalahan yang dihadapi. Penelitian ini 
mengambil data - data yang dikumpulkan dari laporan keuangan publikasi yang telah diaudit selama periode 2012 sampai dengan 2016 oleh BPR di Provinsi Bali.

Pengujian hipotesis dilakukan dengan menggunakan Analisis Diskriminansehingga variabel-variabel yang mampu membedakan antara kedua kelompokdapat diidentifikasi serta menggunakan variabel-variabel yang telah teridentifikasi tersebut untuk menyusun persamaan atau fungsi baru yang dapat digunakan untuk menjelaskan perbedaan antara kedua kelompok. Selain itu, metode analisis data lain yang digunakan dalam penelitian ini adalah statistik deskriptif. Selama proses pengolahan data, penelitian ini menggunakan alat bantu berupa software computer program SPSS. Data statistik variabel independen pada kelompok BPR dengan ROA rendah (ROA dibawah rata-rata industri) dan kelompok BPR dengan ROA tinggi (ROA di atas rata-rata industri) dapat dilihat pada tabel 1 .

Tabel 1.

Deskripsi Statistik Variabel CAR, NPL, LDR, BOPO BPR di Provinsi Bali Periode 2012-2016

\begin{tabular}{llrrrr}
\hline \multicolumn{2}{c}{ Kelompok } & \multirow{2}{*}{ Mean } & Std. Deviation & \multicolumn{2}{c}{ Valid N (listwise) } \\
Unweighted & Weighted \\
\hline RENDAH & CAR & 21,4797 & 19,72095 & 325 & 325,000 \\
& NPL & 5,2822 & 7,18528 & 325 & 325,000 \\
& LDR & 80,4085 & 18,15955 & 325 & 325,000 \\
& BOPO & 86,5449 & 19,37073 & 325 & 325,000 \\
TINGGI & CAR & 23,1508 & 11,23763 & 285 & 285,000 \\
& NPL & 4,1361 & 8,73556 & 285 & 285,000 \\
& LDR & 83,9481 & 11,69973 & 285 & 285,000 \\
\multirow{5}{*}{ Total } & BOPO & 72,0550 & 14,76111 & 285 & 285,000 \\
& CAR & 22,2605 & 16,32478 & 610 & 610,000 \\
& NPL & 4,7468 & 7,96122 & 610 & 610,000 \\
& LDR & 82,0623 & 15,56925 & 610 & 610,000 \\
& BOPO & 79,7751 & 18,80391 & 610 & 610,000 \\
\hline Sumber: Data diolah 2017 & & & &
\end{tabular}

Sumber: Data diolah, 2017 
Jumlah sampel yang digunakan dalam penelitian ini berdasarkan tabel 1 . tersebut sebanyak 122 BPR dengan banyaknya datanya 610, yang terdiri dari 325 Bank Perkreditan Rakyat yang memiliki ROA rendah (ROA di bawah rata-rata industri periode tahun 2012-2016) dan sebanyak 285 Bank Perkreditan Rakyat yang memiliki ROA tinggi (ROA di atas rata - rata industri periode tahun 20122016). Variabel independen dalam penelitian ini ada 4 (empat) antara lain Capital Adequency Ratio (CAR), Non Performing Loans (NPL), Loan to Deposit Ratio (LDR), Biaya Operasional atas Pendapatan Operasional(BOPO). Keempat variabel tersebut dipilih karena merupakan variabel yang sering digunakan dalam meneliti rasio keuangan bank dengan ROA.

Kecukupan modal yang menunjukkan kemampuan bank dalam mempertahankan modal yang mencukupi kemampuan manajemen bank dalam mengidentifikasi, mengukur, mengawasi dan mengontrol risiko-risiko yang timbul yang dapat berpengaruh terhadap besarnya modal bank. Berdasarkan tabel 1 . diketahui bahwa rata-rata kecukupan modal perusahaan untuk kelompok BPR dengan ROA rendah memiliki rata-rata $21,47 \%$ lebih rendah dibanding dengan rata-rata ROA untuk kelompok BPR dengan ROA tinggi yaitu sebesar 23,15\%. Hasil perhitungan rata - rata kecukupan modal dari kedua kelompok BPR menunjukkan bahwa bank - bank yang berukuran besar memiliki rasio profitabilitas di atas rata - rata ROA industri BPR. Semakin besar CAR maka semakin besar kesempatan bank dalam menghasilkan laba karena dengan modal yang besar, manajemen bank sangat leluasa dalam menempatkan dananya kedalam aktivitas investasi yang menguntungkan. Tingkat penyimpangan yang 
diukur dengan standar deviasi kecukupan modal untuk kelompok BPR dengan ROA rendah sebesar 19,72\% lebih tinggi daripada kelompok BPR dengan ROA tinggi yang memiliki nilai sebesar $11,23 \%$.

Kelompok BPR dengan ROA rendah memiliki rata - rata Non Performing Loan (NPL) yang lebih tinggi yaitu sebesar 5,28\% dibandingkan dengan kelompok BPR dengan ROA tinggi yang memiliki rata - rata Non Performing Loan (NPL) sebesar 4,13\%. Perbedaan rata - rata NPL menunjukkan bahwa BPR yang memiliki rasio profitabilitas diatas rata - rata ROA industri cenderung memiliki kemampuan yang lebih baik dalam memantau dan menjaga kualitas dalam penyaluran kreditnya ke masyarakat. Standar deviasi NPL untuk kelompok BPR dengan ROA tinggi dan kelompok BPR dengan ROA rendah sangat kecil yaitu sebesar $7,18 \%$ dan $8,73 \%$.

Loan to Deposit Ratio (LDR) adalah rasio yang mengukur kemampuan bank untuk memenuhi kewajiban keuangan yang harus segera dipenuhi. LDR merupakan perbandingan antara total kredit dengan Dana Pihak Ketiga (DPK). Rata - rata LDR dari kelompok BPR dengan ROA rendah yaitu sebesar 80,40\% lebih rendah di bandingkan dengan kelompok BPR dengan ROA tinggi yakni sebesar $83,94 \%$. Hasil perhitungan tersebut menunjukkan bahwa rata - rata LDR dari kedua kelompok BPR menunjukkan kelompok BPR dengan ROA tinggi selama tahun 2012-2016 cenderung lebih baik dalam melakukan fungsi intermediasi, yaitu menyalurkan dana pihak ketiga dalam bentuk kredit di bandingkan dengan kelompok BPR dengan ROA rendah. Standar deviasi dari LDR untuk kelompok BPR rendah maupun kelompok BPR tinggi, yaitu masing - 
masing sebesar $18,15 \%$ dan $11,69 \%$ yang memiliki nilai cukup kecil. Jika semakin tinggi LDR suatu bank, maka menunjukkan bahwa kemampuan bank tersebut dalam menyalurkan kembali dana yang diterimanya dalam bentuk kredit ke masyarakat berarti semakin baik, hal tersebut dapat mengurangi idle money dan opportunity cost.

Bank Perkreditan Rakyat (BPR) yang termasuk kedalam kelompok BPR dengan ROA rendah memiliki rata - rata Biaya Operasional atas Pendapatan Operasional(BOPO) yaitu sebesar 86,54\% lebih tinggi daripada kelompok BPR dengan ROA tinggi yang memiliki rata - rata sebesar 72,05\%. Perbedaan rata rata BOPO tersebut menunjukkan bahwa BPR yang termasuk kelompok BPR dengan ROA tinggi lebih efisien dalam mengelola operasionalnya, dimana BPR mampu menekan biaya operasional dan meningkatkan pendapatan operasionalnya. Hal tersebut berbanding terbalik dengan kelompok BPR dengan ROA rendah yang memiliki rata - rata BOPO tinggi yang berarti semakin tidak efisien biaya operasional bank. Standar deviasi BOPO untuk masing - masing kelompok BPR dengan ROA rendah lebih tinggi, yaitu sebesar 19,37\% sementara standar deviasi BOPO untuk kelompok BPR dengan ROA tinggi yaitu sebesar $14,76 \%$.

Uji statistik Wilk's Lamda atau F-test dilakukan untuk mengetahui apakah keempat variabel independen dapat membedakan secara signifikan tingkat profitabilitas BPR, dilakukan dengan menggunakan Wilk's Lamda atau F-test. Semakin besar nilai Wilk's Lamda, maka semakin kecil kemungkinan hipotesis 
nol ditolak. Pengujian hipotesis dengan F-test dilakukan dengan cara membandingkan nilai Sig. dengan tingkat signifikansi 5\% atau 0,05.

Tabel 2.

Test of Equality of Group Means

\begin{tabular}{lrrrrrr}
\hline & Wilks' Lambda & \multicolumn{1}{c}{ F } & df1 & & df2 & \multicolumn{1}{c}{ Sig. } \\
\hline CAR & 0,997 & 1,593 & 1 & 608 & 0,207 \\
NPL & 0,995 & 3,158 & 1 & 608 & 0,076 \\
LDR & 0,987 & 7,937 & 1 & 608 & 0,005 \\
BOPO & 0,852 & 105,659 & 1 & 608 & 0,000 \\
\hline Sumber: Data diolah, 2017 & & & &
\end{tabular}

Hasil uji hipotesis dengan menggunakan Wilk's Lamda dan F-test adalah hasil pengujian Capital Adequacy Ratio (CAR) (X1) diperoleh nilai Wilk's Lamda sebesar 0,997 dan nilai sig. 0,207 >0,05 yang berarti bahwa dari hasil pengujian tersebut tidak terdapat perbedaan rata - rata yang signifikan pada CAR antara kelompok BPR yang memiliki ROA tinggi dengan kelompok BPR yang memiliki ROA rendah, sehingga CAR BPR tidak berpengaruh secara signifikan dapat membedakan tingkat rasio profitabilitas.

Hasil pengujian Non Performing Loan (NPL) (X2) diperoleh nilai Wilk's Lamda sebesar 0,995 dan nilai sig. 0,076>0,05 yang berarti bahwa dari hasil pengujian tersebut tidak terdapat perbedaan rata - rata yang signifikan pada NPL antara kelompok BPR yang memiliki ROA tinggi dengan kelompok BPR yang memiliki ROA rendah, sehingga NPL BPR tidak berpengaruh secara signifikan dapat membedakan tingkat rasio profitabilitas.

Hasil pengujian Loan to Deposit Ratio (LDR) (X3) diperoleh nilai Wilk's Lamda sebesar 0,987 dan nilai sig. 0,005 $<0,05$ yang berarti bahwa dari hasil pengujian tersebut terdapat perbedaan rata - rata yang signifikan pada LDR antara 
kelompok BPR yang memiliki ROA tinggi dengan kelompok BPR yang memiliki ROA rendah, sehingga LDR BPR berpengaruh positif dan signifikan dapat membedakan tingkat rasio profitabilitas.

Hasil pengujian Biaya Operasional terhadap PendapatanOperasional (BOPO) (X4) diperoleh nilai Wilk's Lamda sebesar 0,852 dan nilai sig. 0,000< 0,05 yang berarti bahwa dari hasil pengujian tersebut terdapat perbedaan rata rata yang signifikan pada BOPO antara kelompok BPR yang memiliki ROA tinggi dengan kelompok BPR yang memiliki ROA rendah, sehingga BOPO BPR berpengaruh positif dan signifikan dapat membedakan tingkat rasio profitabilitas.

Metode yang digunakan untuk menyelesaikan persamaan diskriminan dalam penelitian ini adalah metode simultan (Simultancous Estimation), yaitu keempat variabel rasio keuangan yang merupakan variabel independen dimasukkan secara bersama - sama dalam analisis untuk menentukan kemampuan dari seluruh variabel independen yang memprediksi apakah suatu BPR termasuk kelompok BPR dengan ROA tinggi (memiliki rata - rata ROA di atas industri) atau kelompok BPR dengan ROA rendah (memiliki rata - rata ROA di bawah industri).

Tabel 3.

Koefisien Fungsi Diskriminan yang Distandardisasi (Standardized Canonical Discriminant Function) dan yang Tidak Distandardisasi (Unstandardized Canonical Discriminant Function)

\begin{tabular}{lcr}
\hline $\begin{array}{c}\text { Variabel } \\
\text { pembeda }\end{array}$ & $\begin{array}{c}\text { Standardized } \\
\text { Canonical } \\
\text { Discriminant } \\
\text { Function Coefficients }\end{array}$ & $\begin{array}{c}\text { Unstandardized } \\
\text { Canonical Discriminant } \\
\text { Function Coefficients }\end{array}$ \\
\hline CAR & $-0,217$ & $-0,013$ \\
NPL & 0,043 & 0,005 \\
LDR & $-0,259$ & $-0,017$
\end{tabular}




\begin{tabular}{lrr}
\hline $\begin{array}{c}\text { Variabel } \\
\text { pembeda }\end{array}$ & $\begin{array}{c}\text { Standardized } \\
\text { Canonical } \\
\text { Discriminant } \\
\text { Function Coefficients }\end{array}$ & $\begin{array}{c}\text { Unstandardized } \\
\text { Canonical Discriminant } \\
\text { Function Coefficients }\end{array}$ \\
\hline CAR & $-0,217$ & $-0,013$ \\
NPL & 0,043 & 0,005 \\
LDR & $-0,259$ & $-0,017$ \\
BOPO & 0,948 & 0,055 \\
(Constant) & & $-2,711$ \\
\hline Sumber: Data diolah, 2017 & & \\
\hline
\end{tabular}

Tabel 3. menunjukkan fungsi diskriminan dengan metode Simultancous Estimation adalah berdasarkan Standardized Canonical Discriminant Function (SCDF):

$$
Z=-0,217 X 1+0,043 X 2-0,259 X 3+0,948 X 4
$$

Berdasarkan Unstandardized Canonical Discriminant Function (UCDF):

$$
Z=-0,013 X 1+0,005 X 2-0,017 X 3+0,055 X 4
$$

Berdasarkan persamaan dari Standardized Canonical Discriminant Function (SCDF) diketahui variabel - variabel yang berperan dalam membedakan rasio profitabilitas BPR adalah keempat rasio keuangan yang menjadi variabel independen dan berdasarkan persamaan Unstandardized Canonical Discriminant Function (UCDF) diketahui nilai - nilai diskriminan dari kedua kelompok BPR (BPR dengan ROA tinggi dan ROA rendah). Maka berdasarkan nilai - nilai diskriminan pada persamaan Unstandardized Canonical Discriminant Function (UCDF) diketahui bahwa rasio keuangan yang dominan membedakan tingkat profitabilitas BPR adalah Biaya Operasional atas Pendapatan Operasional(BOPO) dengan koefisien diskriminan sebesar 0,055. Berdasarkan hasil pengujian tersebut di harapkan pihak BPR atau pengurus agar senantiasa memperhatikan mengenai biaya operasional dengan pendapatan operasional. Hal ini dikarenakan jika 
perusahaan tidak efisien dalam mengelola biaya operasionalnya, maka berarti kurangnya kemampuan perusahaan tersebut dalam menekan biaya operasional dan meningkatkan pendapatan operasionalnya, yang akan dapat menimbulkan kerugian.

Fungsi diskriminan yang terbentuk berguna untuk memprediksi apakah suatu BPR termasuk kelompok BPR dengan ROA rendah (memiliki ROA dibawah rata-rata industri) atau kelompok BPR dengan ROA tinggi (memiliki ROA di atas rata - rata industri) berdasarkan kinerja keuangan perbankan yang meliputi Capital Adequency Ratio (CAR) (X1), Non Performing Loans (NPL)(X2), Loan to Deposit Ratio (LDR)(X3), Biaya Operasional atas Pendapatan Operasional(BOPO)(X4).

Canonical correlation menunjukkan keeratan hubungan antara discriminant score dengan group. Nilai dari canonical correlation sebesar 0,402 mendekati 1 (satu) menunjukkan keempat variabel independen sebagai pembeda dari rasio profitabilitas bank yang memiliki hubungan yang kuat dalam menentukan perbedaan rasio profitabilitas antara kelompok BPR dengan ROA rendah dan kelompok BPR dengan ROA tinggi.

Tabel 4.

Analisa Eigenvalues

\begin{tabular}{lcccc}
\hline Function & Eigenvalue & \% of Variance & Cumulative \% & $\begin{array}{c}\text { Canonical } \\
\text { Correlation }\end{array}$ \\
\hline 1 & 100 & 100 & 0,402 \\
\hline Sumber : Data diolah, 2017 & & &
\end{tabular}

Pada tabel 4. terdapat nilai canonical correlation, yang digunakan untuk mengukur derajat hubungan antara hasil diskriminan atau besarnya variabilitas 
yang mampu diterangkan oleh variabel independen yaitu Capital Adequency Ratio (CAR) (X1), Non Performing Loans (NPL) (X2), Loan to Deposit Ratio (LDR) (X3), dan Biaya Operasional atas Pendapatan Operasional(BOPO) (X4) terhadap variabel dependen yaitu kelompok BPR dengan ROA tinggi dan kelompok BPR dengan ROA rendah. Nilai canonical correlation yang diperoleh dari tabel 5.4 tersebut sebesar 0,402 atau besarnya Square Canonical Correlation $\left(\mathrm{CR}^{2}\right)=$ $(0,402)^{2}$ yaitu sama dengan 0,161 artinya $16,1 \%$ varians antara kelompok BPR dengan ROA tinggi dan kelompok BPR dengan ROA rendah dapat di jelaskan oleh variabel diskriminan rasio Capital Adequency Ratio (CAR) (X1), Non Performing Loans (NPL) (X2), Loan to Deposit Ratio (LDR) (X3), dan Biaya Operasional atas Pendapatan Operasional(BOPO) (X4).

Nilai canonical correlation sebesar 0,402 yang dapat disimpulkan bahwa keempat variabel independen secara bersama - sama dapat mempengaruhi rasio profitabilitas BPR sebesar 40,2 \% dan 59,8\% dipengaruhi oleh faktor lain diluar model, seperti misalnya faktor manajemen atau rasio keuangan lainnya yang tidak menjadi variabel independen dalam penelitian ini.

Tabel 5.

Wilk's Lamda

\begin{tabular}{lrrrrr}
\hline Test of Function(s) & Wilks' Lambda & Chi-square & df & \multicolumn{1}{c}{ Sig. } \\
\hline 1 & 0,839 & 106,738 & 4 & 0,000 \\
\hline Sumber : Data diolah, 2017 & & & &
\end{tabular}

Tabel 5. menunjukkan angka chi-square sebesar 106,738 dan nilai sig. $0,000<0,05$, berarti bahwa tingkat signifikansi yang sangat tinggi. Maka hal ini mencerminkan bahwa adanya perbedaan yang signifikan antara kelompok BPR dengan ROA tinggi dan kelompok BPR dengan ROA rendah. 
Model analisis yang telah dibagun dari analisis diskriminan tadi kemudian diuji untuk mengetahui seberapa besar kemampuannya dalam melakukan prediksi pengelompokkan BPR menjadi kelompok BPR dengan ROA tinggi dan kelompok BPR dengan ROA rendah. Keakuratan dalam model prediksi dapat diketahui dengan membandingkan angka $Z$ score yang didapat dari fungsi diskriminan dibandingkan dengan $Z$ cutting score. Angka $Z$ cutting score dihitung dengan menggunakan angka dari $Z$ centroid yang akan menjadi patokan dalam menentukan kelompok BPR dengan ROA tinggi dan ROA rendah.

Tabel 6.

Hasil Klasifikasi Kelompok BPR

\begin{tabular}{|c|c|c|c|c|c|}
\hline & & \multicolumn{4}{|c|}{ Predicted Group Membership } \\
\hline & & Kelompok & RENDAH & TINGGI & Total \\
\hline \multirow[t]{4}{*}{ Original } & Count & RENDAH & 254 & 71 & 325 \\
\hline & & TINGGI & 57 & 228 & 285 \\
\hline & $\%$ & RENDAH & 78,2 & 21,8 & 100 \\
\hline & & TINGGI & 20,0 & 80,0 & 100 \\
\hline
\end{tabular}

Tabel 6. menunjukkan bahwa pada data untuk kelompok BPR dengan ROA rendah 325 BPR. Berdasarkan klasifikasi fungsi diskriminan, yang tetap pada kelompok BPR dengan ROA rendah adalah 254 BPR atau dengan persentase kasus diklasifikasi secara benar sebesar 78,2\%. Kemudian sebanyak 71 BPR pada awalnya termasuk dalam kelompok BPR dengan ROA rendah, namun setelah klasifikasi fungsi diskriminan menjadi kelompok BPR dengan ROA tinggi atau kelompok BPR dengan ROA diatas rata - rata atau terjadi kesalahan klasifikasi sebesar $21,8 \%$. 
Pada awalnya jumlah BPR yang masuk ke dalam kelompok BPR dengan ROA diatas rata - rata (kelompok BPR dengan ROA tinggi) sebanyak 285 BPR. Namun, sebanyak 57 BPR yang pada data awal termasuk BPR dengan ROA tinggi, kemudian setelah klasifikasi fungsi diskriminan menjadi anggota kelompok BPR dengan ROA rendah (memiliki ROA di bawah rata - rata) atau terjadi kesalahan klasifikasi sebesar 20\%.

Ketepatan prediksi dari model diskriminan yang telah dilakukan adalah sebesar $79 \%$ yang mencerminkan model diskriminan yang terbentuk tersebut bisa digunakan untuk memprediksi pengelompokkan suatu BPR sebagai kelompok BPR dengan ROA tinggi (di atas rata - rata) atau kelompok BPR dengan ROA rendah (di bawah rata - rata ).

Hasil hitung rata - rata nilai diskriminan masing - masing kelompok kinerja keuang BPR dalam fungsi diskriminan diperoleh nilai sebagai berikut :

a) Centroid untuk kelompok BPR dengan ROA rendah atau di bawah rata - rata sebesar 0,410 .

b) Centroid untuk kelompok BPR dengan ROA tinggi atau di atas rata - rata sebesar $-0,468$.

Batas nilai $Z$ antara kelompok BPR dengan ROA rendah dan ROA tinggi dengan menggunakan $Z$ centroid adalah sebagai berikut :

$$
\begin{aligned}
Z \text { cutting score } & =\frac{(325)(-0,468)+(285)(0,410)}{(325+285)} \\
& =-0,057
\end{aligned}
$$

Berdasarkan perhitungan $Z$ cutting score di atas, diketahui beberapa hal sebagai berikut: 1) Suatu BPR dikategorikan sebagai kelompok BPR dengan ROA 
rendah (kelompok atau group 0), jika memiliki $Z$ cutting score dibawah $-0,057$ ( $Z$ cutting score <-0,057). 2) Suatu BPR dikategorikan sebagai kelompok BPR dengan ROA tinggi (kelompok atau group 1), jika memiliki $Z$ cutting score diatas $-0,057$ ( $Z$ cutting score $>-0,057)$.

Fungsi diskriminan yang telah terbentuk dan hasil perhitungan $Z$ cutting score selanjutnya digunakan untuk mengklasifikasi BPR - BPR ke dalam kelompok BPR dengan ROA rendah atau ROA tinggi, yang mencerminkan posisi tingkat profitabilitas BPR jika dibandingkan dengan industri.

Tabel 7.

Koefisien Fungsi Klasifikasi Masing - Masing Kelompok

Kelompok

\begin{tabular}{lrr} 
& RENDAH & \multicolumn{1}{c}{ TINGGI } \\
\hline CAR & 0,108 & 0,120
\end{tabular}

NPL $\quad 0,083 \quad 0,078$

LDR $\quad 0,371 \quad 0,385$

BOPO $\quad 0,286 \quad 0,238$

\begin{tabular}{lrr} 
(Constant) $\quad-29,329$ & $-26,974$ \\
\hline Sumber : Data diolah, 2017
\end{tabular}

Tabel 7. menunjukkan persamaan fungsi diskriminan untuk masing masing kelompok BPR, yaitu :

Persamaan fungsi diskriminan untuk kelompok BPR dengan ROA di bawah rata rata atau ROA rendah adalah :

$$
Z=-29,329+0,108 X 1+0,083 X 2+0,371 X 3+0,286 \times 4
$$

Persamaan fungsi diskriminan untuk kelompok BPR dengan ROA di atas rata rata atau ROA tinggi adalah :

$$
Z=-26,974+0,120 X 1+0,078 \times 2+0,385 \times 3+0,238 X 4
$$


Perhitungan nilai diskriminan pada setiap kelompok observasi akan menghasilkan pemisahan kelompok yang penyebarannya baik dalam bentuk histogram gabungan dan histogram masing - masing kelompok.

\section{SIMPULAN DAN SARAN}

Berdasarkan hasil penelitian dan pembahasan pada bab sebelumnya, maka didapat kesimpulan bahwa Loan Deposit Ratio (LDR) merupakan ukuran likuiditas bank dan Biaya Operasional atas Pendapatan Operasional (BOPO) mampu secara signifikan membedakan tingkat profitabiltas tinggi atau profitabilitas rendah BPR di Provinsi Bali. Peningkatan rasio LDR berpengaruh positif pada peningkatan tingkat Profitabilitas, hal ini berarti bahwa rasio LDR yang semakin tinggi mengindikasikan semakin banyak jumlah dana pihak ketiga yang disalurkan dalam bentuk kredit sehingga akan menghasilkan pendapatan bunga yang tinggi. Sebaliknya, peningkatan rasio BOPO berpengaruh positif dan signifikan pada peningkatan profitabilitas berarti bahwa adanya pendapatan diluar operasional atau pendapatan non operasional yang lebih tinggi yang mampu meng-cover biaya operasional yang tinggi dan rendahnya pendapatan operasional.

Capital Adequency Ratio (CAR) yang menunjukan kecukupan modal bank dan Non Performing Loan (NPL) yang menunjukan kemampuan bank dalam mengukur risiko kegagalan pengembalian kredit tidak berpengaruh secara signifikan membedakan Tingkat Profitabiltas Tinggi atau Profitabilitas Rendah BPR di Provinsi Bali. Hal ini berarti menunjukkan bahwa besar kecilnya kecukupan modal bank (CAR) belum tentu menyebabkan besar kecilnya 
keuntungan bank. Kurangnya BPR dalam dimitigasi NPL dengan baik, sehingga terjadinya pemasalahan dalam pemberian kredit.

Berdasarkan hasil penelitian, berikut ini beberapa saran untuk manajemen Bank Perkreditan Rakyat di Provinsi Bali, yaitu pengurus bank dapat menggunakan 4 rasio keuangan bank secara bersama - sama meliputi Capital Adequacy Ratio (CAR), Non Performing Loan (NPL), Loan to Deposit Ratio (LDR) dan Biaya Operasional terhadap PendapatanOperasional (BOPO) untuk memprediksi pengelompokkan bank berdasarkan tingkat profitabilitasnya. Keempat rasio tersebut dimasukkan dalam fungsi diskriminan (UCDF), sehingga dapat diperoleh nilai Z (zetta score). Nilai selanjutnya dibandingkan dengan besarnya nili kritis $Z$ (cutting score) untuk mengetahui apakah suatu bank termasuk kelompok bank dengan ROA tinggi atau rendah.

Penelitian ini menemukan hasil bahwa Biaya Operasional terhadap PendapatanOperasional (BOPO) merupakan rasio keuangan yang paling dominan membedakan tingkat profitabilitas bank, sehingga pengurus bank diharapkan lebih efisien dan efektif dalam pengelolaan biaya operasionalnya.

Penelitian selanjutnya dapat meneliti lebih lanjut dua rasio keuangan yaitu Capital Adequacy Ratio (CAR) dan Non Performing Loan (NPL) yang dalam penelitian ini diketahui tidak secara signifikan dapat membedakan tingkat profitabilitas bank. Selain itu juga dapat meneliti variabel - variabel keuangan lainnya, seperti Ukuran bank, Cash Ratio, Total Equity To Total Liabilities Ratio, dan rasio - rasio lainnya yang dapat mempengaruhi profitabilitas. 


\section{REFERENSI}

Abdullah, M.N. \& Jahan, N. 2014. The Impact Of Liquidity on Profitability in Banking Sector of Bangladesh : a Case of Cittagong Stock Exchange. EPRA International Journal of Economic and Business, Vol.2, No.10, pp. $17-22$.

Adebisi J \& Matthew O. 2015. The Impact of Non-Performing Loans on Firm Profitability: A Focus on the Nigerian Banking Industry. American Research Journal of Business and Management, Vol.1, pp. 1-7.

Adyani, Lyla Rahma. 2011. Analisis Faktor-Faktor Yang Mempengaruhi Profitabilitas. Jurnal Ekonomi dan Bisnis Universitas Diponegoro.

Artarina, O. \& Masdjojo, G.N. 2013. Faktor-Faktor Yang Mempengaruhi Rentabiltas Pada BPR Di Kabupaten Blora. Jurnal Akuntansi Keuangan dan Perbankan, Vol.2, No.1, pp.44-51.

Buchory, H.A.2015. Banking Profitability: How does the Credit Risk and Operational Efficiency Effect. Journal of Business and Management Sciences, Vol.3, No.4, pp.118-123.

Buchory, H.A.2015. Banking Intermediation, Operational Efficiency And Credit Risk In The Banking Profitability. International Journal of Business, Economics and Law, Vol.7, 57-63.

Budisantoso, Totok \& Nuritomo.2014. Bank dan Lembaga keuangan Lain. Jakarta: Salemba Empat. Hal : 11.

Cai, M. \& Huang, Z. 2014. Analysis of non- performing loan and capital adequacy ratio among Chinese banks in the post-reform period in China. Journal of Advanced Studies in Finance, Vol. 5, No.10, pp.133-144.

Dawood, Usman. 2014. Factors impacting profitability of commercial banks in Pakistan for the period of (2009-2012). International Journal of Scientific and Research Publications. Vol.4(3),pp.1-7. ISSN 2250-3153.

Defri. 2012. Pengaruh capital adequacy ratio, likuiditas dan efisiensi operasional terhadap profitabilitas perusahaan perbankan yang terdaftar di bursa efek indonesia. Jurnal Manajemen, Vol. 1, No.1, pp.1-18.

Eng, Tan Sau. 2013. Pengaruh NIM, BOPO, LDR, and CAR terhadap ROA Bank Internasional and Go Public Periode 2007-2011. Jurnal Dinamika Manajemen, Vol.1, No.3 : 153-167. 
Hair, Joseph F., Anderson Rolph E., Tahtham, Ronald L., Black, William C.2010. Multivariance Data Analysis, $7^{\text {th }}$ Edition. New York Jersey : Prentice Hall International, Inc.

Hantono. 2017. Effect Of Capital Adequacy Ratio (CAR), Loan To Deposit Ratio (LDR), and Non Performing Loan (NPL) to Return On Assets (ROA) Listed In Bangking In Indonesia Stock Exchange. International Journal of Education and Research,Vol.5, No.1, pp.69-80.

Kasmir. 2011. Bank dan Lembaga Keuangan Lainnya. Jakarta: PT. Rajagrafindo Persada.

Kristianti, Yovin. 2016. Factors Affecting Bank Performance: Cases of Top 10 Biggest Government and Private Banks in Indonesia in 2004 - 2013. Rev. Integr. Bus. Econ. Res, Vol 5, 371-378.

Kuncoro, M. \& Suharjono. 2011. Manajemen Perbankan Teori dan Aplikasi. Edisi Kedua. Yogyakarta: BPFE.

Murdiyanto, Agus.2012.Faktor-faktor yang Berpengaruh dalam Penentuan Penyaluran Kredit Perbankan: Studi pada Bank Umum Di Indonesia Periode 2006-2011.Procceding of Conference in Business, Acounting and Management (CBAM) UNISSULA, Vol.1, No.1.

Paulin, O. \& Wiryono, S.K. 2015. Determinants of Islamic Bank's Profitability in Indonesia For 2009-2013. Journal of Business and Management, Vol.4, No.1, pp.175-185.

Prasetyo, D.A. \& Darmayanti, A. 2015. Pengaruh Risiko Kredit Likuiditas, Kecukupan Modal. dan Efisiensi Operasional Terhadap Profitabilitas Pada PT BPD Bali. E-Jurnal Manajemen Unud, Vol.4, No.4, pp.2590-2617.

Pratiwi, Dhian Dayinta.2012.Pengaruh CAR, BOPO, NPF, dan FDR Terhadap Return On Asset (ROA) Bank Umum Syariah.Fakultas Ekonomi dan Bisnis.Universitas Diponegoro Semarang.

Premani, Y. \& Badjra, I.B. 2014. Analisis Determinasi Profitabilitas LPD Kecamatan Kuta dan LPD Kecamatan Mengwi. E-Jurnal Manajemen Universitas Udayana.

Purnamawati. 2014.The Effect Of Capital And Liquidity Risk To Profitability On Conventional Rural Bank In Indonesia. South East Asia Journal of Contemporary Business, Economics and Law, Vol. 5, 44-50.

Puspitasari, D \& Setiadi N \& Rizkiyanti N.2016.Implementation Of The Indonesian Banking Architecture As A Blueprint Of The Direction And 
Order Of The National Banking System: Empirical Study Of Indonesian Commercial Banking. Journal The WINNERS, Vol.16, 6-14.

Rengasamy, D. 2014. Impact of Loan Deposit Ratio (LDR) on Profitability: Panel Evidence from Commercial Banks in Malaysia. Proceedings of the Third International Conference on Global Business, Economics, Finance and Social Sciences (GB14Mumbai Conference) Mumbai, India, pp.1-11.

Riyadi, S. 2006. Banking Assets and Liability Management. Jakarta: Lembaga Penerbit Fakultas Ekonomi Universitas Indonesia.

Santoso, Singgih.2015.Menguasai Statistik Multivariat : Konsep Dasar dan Aplikasi dengan SPSS. Jakarta : PT Elex Media Komputindo.

Susanto, H. \& Kholis, N.2016.Analisis Rasio Keuangan terhadap Profitabilitas pada Perbankan Indonesia Financial Ratio Analysis toward Profitability on Indonesian Banking.Jurnal EBBANK, Vol.7, No. 1, Hal.11-22. Juni 2016.

Utami, S. 2015. Comparison Between Bank Performance Of Commercial Bank, State Owned Bank, and Foreign Owned Bank In Indonesia During The Period 2005-2009. International Journal of Advanced Research in Management and Social Sciences, Vol.4, pp.37-54.

Wiagustini. 2010. Dasar-Dasar Manajemen Keuangan. Denpasar: Udayana University Press.

Wibowo, E.S \& Syaichu,Muhammad. 2013. Analisis Pengaruh Suku Bunga, Inflasi, CAR, BOPO, NPF Terhadap Profitabilitas Bank Syariah. Diponegoro Journal Of Management, Vol.2, No.2, pp.1-10.ISSN (Online): 2337-3792

Zulfikar, T. 2014. Pengaruh CAR, LDR, NPL, BOPO dan NIM terhadap Kinerja Profitabilitas (ROA) Bank Perkreditan Rakyat di Indonesia. E-Journal Graduated Unpar.

www.bi.go.id www.ojk.go.id wWw.wikipedia.org 